\title{
Censure: moral and sociological
}

\author{
Lindsay Farmer* \\ University of Glasgow
}

\section{Introduction}

The concept of censure is central to two influential theories, both developed at the University of Cambridge in the 1980s and 1990s. On the one hand, there is Colin Sumner's ambitious attempt to reconstruct the theoretical foundations of the discipline of criminology by replacing the sociology of deviance with a sociology of censure. ${ }^{1}$ On the other hand, there is Andreas von Hirsch's development of a theory of punishment and criminal law that was also organised around the central concept of censure. A I shall show, both theories can be read as responses to the decline of penal-welfarism and to the shifts in penal policy and practice that accompanied the rise of neo-liberalism in this period. However, in spite of this, and the fact that they share the central concept of censure, it is curious that they do not engage with each other. Sumner's account is sociological; von Hirsch's is normative. The former opens up the possibility of a social account of criminal law and punishment that is linked to economic and political institutions; the latter is concerned with the fairness of individual punishment, seeking to engage with normative dimensions of censure and disapproval and to articulate the grounds on which censure, and thus punishment, might be justified. Thus, while the two theories are both concerned with crime and punishment, they talk past each other and make no attempt to engage with the other. In this paper, then, I want to explore the possible relationships, if any, between the two concepts of censure and to look at whether the concept of censure might be used in a way which brings the two approaches closer together.

\section{A Sociology of Censure}

Sumner's distinctive account aims at a reconstruction of criminology as a sociology of censure. $^{2}$ This is comprised of two interconnected strands, one rooted in his work on a Marxist concept of ideology and the other in a historical analysis of the sociology of deviance.

The first strand was developed in Sumner's work from the 1970s onwards - in part as a critique of the (at the time) dominant sociology of deviance, and also in an engagement with strands of radical criminology which variously sought to construct, or to reject the possibility of, a Marxist theory of crime and deviance. ${ }^{3}$ Sumner argued that the underlying problem with the sociology of deviance, and with Marxist attempts to radicalise the analysis of deviance, was that it treated 'deviance' and crime as though they were objective social

\footnotetext{
* I would like to thank Sarah Armstrong for her comments on an earlier draft.

${ }^{1}$ C Sumner, The Sociology of Deviance. An Obituary (Buckingham: Open University Press, 1994)

${ }^{2}$ See e.g. C Sumner, "Marxism and Deviancy Theory" in P Wiles (ed), The Sociology of Crime and Delinquency in Britain (London: Martin Robertson, 1976); C Sumner (ed), Censure, Politics and Criminal Justice (Buckingham: Open University Press, 1990); "The Social Nature of Crime and Deviance" in Sumner (ed), The Blackwell Companion to Criminology (Oxford: Blackwell, 2004). I have greatly benefited from reading D Moxon, "Marxism and the Definition of Crime" (2011) 5(2) In-Spire Journal of Law, Politics and Society 102-20.

${ }^{3}$ See I Taylor, P Walton \& J Young, The New Criminology (London: Routledge \& Kegan Paul, 1973); See also essays in I Taylor, P Walton \& J Young (eds.), Critical Criminology (London: Routledge \& Kegan Paul, 1975). These are discussed in Sumner, Sociology of Deviance, ch.10.
} 
categories. This meant that the discipline of criminology was thrown onto investigating the characteristics of criminals or 'deviants' in order to explain the phenomenon of crime, rather than looking at the way that the categories of deviance or crime were themselves constructed and deployed. ${ }^{4}$ These categories, he argued, were based on an implicit claim to moral and political consensus, against which deviance was to be judged. Thus, rather than focusing on the behaviour or conduct, it was important to focus on the means by which the consensus the dominant moral or political code - was constructed and thus how certain behaviours come to be labelled as deviant. If there was no underlying reality of crime or deviance, what these concepts had in common was that they were conduct that had been labelled as such by the state. This required a recognition that criminal or moral judgments were not based on any objective reality, but reflected social and class conflicts over meaning. Thus, as Stuart Hall and his collaborators famously argued, the category of mugging was deployed in the early 1970 s by state and media as a form of censure which enabled a new kind of 'law and order' politics. ${ }^{5}$ From this perspective, then, deviance was to be understood as an ideological concept, in the sense that it was used as a way of producing a particular world view that reflected class interests, and that therefore the way forward was to use a theory of ideology as a means of developing the analysis. ${ }^{6}$ The concept of censure was thus intended to open up historical and sociological analysis of the way that judgments about deviancy were made, about the meaning of conduct to the participants, and of the kind of social, political and economic interests that censures represented. Censures were thus defined as "negative ideological categories with specific historical application".

The second strand is most clearly articulated in his book The Sociology of Deviance: An Obituary (1994), in which Sumner argued that the sociology of deviance is tied to a particular governmental project, itself connected to the development and decline of the welfare state. ${ }^{8}$ The origins of the sociology of deviance were traced to the foundational work of Emile Durkheim, which while recognising deviance as a social phenomenon also saw the role of the state as being that of managing and controlling deviance. This governmental project then developed over the course of the twentieth century as deviancy theory was connected to institutional developments in criminal justice and 'corrections'. However, Sumner argues that the study of deviancy ran its course as both an intellectual and a governmental project in the 1960s and 1970s as the post-World War Two consensus unravelled. The intellectual unravelling began with the work of those such as Matza who questioned taking deviancy as the central category of analysis and focused instead on the role of the state (or state actors) in defining deviant conduct and the building of 'deviant' identities - in particular in relation to forms of 'deviant' conduct such as drug taking or homosexuality. ${ }^{9}$ Once it was recognised that ideas about deviancy relied on an implicit account of a dominant normative order, it was essential to study how that order itself was created. For those following Matza, the study of deviancy thus increasingly shifted from the nature of the conduct or 'deviants' themselves to the bodies or processes that defined or labelled conduct as deviant. Sumner then goes on to argue that this contradiction between the

\footnotetext{
${ }^{4}$ See Sociology of Deviance, pp.309-10 for a summary discussion of the weaknesses of category of deviance.

${ }^{5} \mathrm{~S}$ Hall et al, Policing the Crisis. Mugging, the State and Law and Order (Basingstoke: Macmillan, 1978).

${ }^{6}$ Building on his analysis in Reading Ideologies. An Investigation into the Marxist Theory of Ideology and Law (London: Academic Press, 1979)

7 Sumner, "Rethinking Deviance. Towards a Sociology of Censure" in Sumner (ed), Censure, Politics and Criminal Justice (Buckingham: Open University Press, 1990) p.26. See also Sumner, The Sociology of Deviance, p.303.

${ }^{8}$ Supra n.1. See also "Censure, Culture and Political Economy. Beyond the Death of Deviance Debate" in S Hall \& S Winlow (eds), New Directions in Criminological Theory (London: Routledge, 2012).

${ }^{9}$ D Matza, Becoming Deviant (Englewood Cliffs, NJ: Prentice-Hall, 1969).
} 
ameliorative project of the sociology of deviance and state power became even more stark as the welfare state was dismantled, with criminal law being used more nakedly as the exercise of class power. In the absence of a clear shared normative order, criminal law in a neo-liberal order stands revealed as the censure or blaming of conducts that are threatening to social order or morally disapproved of by the dominant socio-economic classes. Here censure seems to have a more specific historical character:

"If the 1960s were a time of deviance, in thought and in action, this new century is a time of censure both in thought and in action." 10

Censure here takes the form of indiscriminate blaming for political purposes to buttress the power of the state or particular social groups: "the eighties marked a return to an older set of judgments about wickedness and its fiscal cost." 11 This socio-historical account of censure thus not only seeks to demonstrate how particular censuring practices are organised around particular themes and the way that these themselves are linked to particular political projects, but also identifies 'censure' as a practice specific to the neo-liberal state.

This is an important and powerful critique of the intellectual project which the sociology of deviance represents. However, there is also a clear sense of normative disapproval in Sumner's usage of the term 'censure' in the work making up this second strand, though the grounds for this are not fully articulated. He condemns the use of the criminal law as a nakedly 'censuring' practice and the depoliticising practices of censuring and blaming others, which he argues characterise contemporary neo-liberal societies:

"It is producing the censorious society of proto-saints - an entropic entity with no goals other than the slander and defeat of the immediate enemy today... The censure

floats free of restraint and has become as anonymously unattached as money." 12 At the same time, he argues for the reinvigoration of a moral code that would censure the practices of the rich and powerful on the basis of a new kind of ethics, based on the building of new kinds of legitimacy. ${ }^{13}$ The 'sociology of censure' can thus describe either the general historical reconstruction of the sociology of deviance, or the more specific historical project of understanding the use of censure and punishment in neo-liberalism or late capitalism, or indeed the reconstructive ethical project hinted at in his more recent writings.

The principal strength of the sociology of censures approach, in my view, is the focus on censuring practices rather than qualities of the conduct itself. Sumner's is a nonessentialist approach that demands that we look at the kinds of censure, the institutional forms that they take, the way that certain normative understandings are built up around these censures, and the way that these are linked to social institutions and power structures. This is exemplified by Sumner's historical analysis of the sociology of deviancy 'project', but can and should be extended to other periods and areas. This kind of approach opens the path to a more systematic analysis of how values come to be organised in a certain way in institutions such as the criminal law so as to ask what is distinctive about censure through the criminal law. In Sumner's more recent work he has introduced a normative dimension to this project, claiming also to see it as an attempt to develop a theory of "morality, democracy and justice"

\footnotetext{
${ }^{10}$ Sumner, "Censure, Culture and Political Economy", p.165.

${ }^{11}$ Sumner, Sociology of Deviance, p.310; Sumner, "Beyond": "From deviance to censure is not just a shift in sociological theory, but also a change in the way societies operate" (p.174).

12 Sumner, Sociology of Deviance, p.313.

${ }^{13}$ Sumner, "Beyond": "There is certainly a need for a critical re-moralization of society" (p.174); "the censure and punishment of the bankers could be the starting point of a new moral order or at least the recognition of the idea and reality of the moral economy" (p.178).
} 
- though the grounds for this remoralization, or its connection to the broader sociology of censure project, are only gestured at. ${ }^{14}$

\section{Censure and Sanctions}

This same period saw a parallel revival of interest in the idea of censure in criminal law theory. Beginning in the 1970s, Andreas von Hirsch was producing a body of work which challenged contemporary sentencing practices, in particular individualised treatment and indeterminate sentences, arguing that sentencing should be strictly proportional to the seriousness of the crime. ${ }^{15}$ This movement was in significant part motivated by the critique of the rehabilitative ideal which developed in the late 1960 and 1970s which identified harsh and indeterminate sentences as one of the major failings of penal-welfarism. This was driven by a liberal, rights-based, agenda - seeking to limit punishment by moving from a consequentialist to a non-consequentialist, retributive, justification for punishment. The aim was to punish less, focusing on not doing harm instead of seeking to do good through punishment. ${ }^{16}$ Doing justice to the accused and to the victims of crime was seen as more important than utilitarian concerns with crime prevention. Penal theory accordingly began to focus on questions of sentencing, seeing the reduction of discretion in sentencing as a way of addressing the abuses of some rehabilitative practices.

Von Hirsch's influential theory of punishment came to focus on the concept of censure, which he identified with the retributive justification of punishment. This was most clearly articulated in his book, Censure and Sanctions (1993). ${ }^{17}$ This took the form of an argument about the justification of punishment. He began this by arguing that censure was a form of blaming or condemnation that was "desert-oriented by nature". ${ }^{18}$ It was desertoriented because on his account a person is entitled to condemn (punish) only if they have reason to believe that conduct is wrongful, and only to the extent of the wrongfulness of the conduct. Punishment which was not for wrongdoing, or whose harshness or severity exceeded the extent of the wrong committed was thus prima facie unjustified. However, he also argued that this form of moral address required to be supplemented with hard treatment (punishment) which would provide the offender with prudential reasons for obedience. ${ }^{19}$ Thus, while there was a linkage between censure, as the general justifying aim of punishment, and a consequentialist concern that punishment was necessary to prevent crime, the sanction was to be understood primarily as a form of censure. Censure appealed to the offender as an agent as part of the process of holding them responsible, or calling them to account, for their conduct. It addressed, first, the victim, or the person who had been wronged, and was an acknowledgement of the wrong that had been done to them. Second, it addressed the wrongdoer(s) and it carried an expectation of some response from them or an acknowledgement of the wrongfulness of their conduct. And third, it addressed the wider community, communicating the disapproval of the wrongdoing and providing reasons for

\footnotetext{
${ }^{14}$ Sociology of Deviance, p.304. See also "Beyond" p.174 calling for a major restatement of the criminal law based on a "democratization and rationalization of social censures".

${ }^{15}$ See in particular Doing Justice. The Choice of Punishments (New York: Hill \& Wang, 1976); Past or Future Crimes. Deservedness and Dangerousness in the Sentencing of Criminals (Manchester: Manchester UP, 1986). There is discussion of the development of his ideas in A Duff \& D Garland, A Reader on Punishment (Oxford: Oxford UP, 1994) pp.112-4.

${ }^{16}$ See the discussion in S Cohen, "Guilt, Justice and Tolerance: Some Old Concepts for a New Criminology" in Against Criminology (London: Transaction, 1998) at pp.131ff.

17 (Oxford: Oxford UP, 1996). See also AE Bottoms, "5 Puzzles in von Hirsch's Theory of Punishment" in A Ashworth \& M Wasik, Fundamentals of Sentencing Theory (Oxford: Oxford UP, 1998) esp. at pp.77-95.

${ }^{18}$ Censure and Sanctions, p.24.

${ }^{19}$ Censure and Sanctions, p.14; Duff \& Garland, Reader, pp.112-3.
} 
desistance from such conduct in future. Censure was thus "embodied in the prescribed sanction" because it was embedded in a complex relational structure of moral agency. ${ }^{20}$

It is central to von Hirsch's account that censure is communicative and expressive, seeing punishment as embodying a form of "social and symbolic communication" between offender, victim and the wider community. ${ }^{21}$ This, in itself, taps into a broader movement in moral philosophy in which it has been argued that the attribution of responsibility is relational, taking place within a broader network of actors and institutions. On this view responsibility should not be understood as a fundamental attribute of the actor (such as free will), but as rooted in social practices of answerability between agents and institutions. This seeks to ground the abstract concept of responsibility in social practices of holding ourselves and others to account. ${ }^{22}$ The very idea of censure thus implies both recognition of the moral agency of victims and perpetrators and a form of moral communication between the various participants. Censure is grounded in the community practices of calling to account and should be understood ideally as promoting a form of moral dialogue in the community. Censure thus has an intrinsic moral and symbolic structure which seeks both to address the wrongdoer about their past wrongdoing and to shape future conduct. ${ }^{23}$ This account of censure also has implications for the substantive criminal law. ${ }^{24} \mathrm{~A}$ legal censure must identify conduct that is wrongful and declare this publicly, and in advance - so that the addressee "should consider its wrongfulness (and not just the threat of adverse consequences) as reason to desist". ${ }^{25}$ The criminal law's claim to legitimate authority thus rests in part on the content of the norm (its wrongfulness) and in part on the modality of law. Criminal law is a form of regulation which addresses legal persons as moral agents. This is thus to identify something distinctive about criminal law which can distinguish it from other modes of crime control or regulation. ${ }^{26}$

This is thus an account of censure which has considerable intellectual coherence and appeal, grounding the justification of punishment and criminal law in an account of individual moral agency and seeing censure as a particular way of identifying and responding to wrongful conduct. Its strength lies in the recognition of offenders as moral agents who are also always part of a wider political community, as well as its commitment to parsimony in punishment. But, these points also raise significant questions. Many of these concerns centre around the question of the legitimacy of censure practices. ${ }^{27}$ For von Hirsch legitimacy can appear to be internal to the concept of censure: if a wrongful act has been committed, and the penalty is not disproportionate to the wrong, then the censure is prima facie legitimate. The difficulty, though, is that the legitimacy of the criminal law and the criminal justice system depends not only on moral, or even legal, reasons but also on a wider range of political and social factors - and for an account that sees censure as authoritative expression of disapproval von Hirsch has remarkably little to say about structures of authority. This point can be

\footnotetext{
${ }^{20}$ Censure and Sanctions, p.11.

${ }^{21}$ Although in his more recent writings he concedes that censure "generally involves authoritative expressions of disapproval": see AP Simester \& A von Hirsch, Crimes, Harms and Wrongs. On the Principles of

Criminalisation (Abingdon: Hart Publishing, 2011) p.13. See also Bottoms, "5 Puzzles" p.86. cf. J Feinberg, "The Expressive Function of Punishment" (1965) 49 The Monist 397-423; RA Duff, Punishment, Communication and Community (Oxford: Oxford UP, 2001).

22 P Strawson, "Freedom and Resentment" in J Fischer \& M Ravizza, Perspectives on Moral Responsibility (Ithaca: Cornell UP, 1993); C Kutz, "Responsibility" in J Coleman et al, The Oxford Handbook of Jurisprudence and Philosophy of Law (Oxford: Oxford UP, 2004).

${ }^{23}$ See Duff, Punishment, at p.80.

${ }^{24}$ Simester \& von Hirsch, Crimes, ch.1.

${ }^{25}$ Simester \& von Hirsch, Crimes, p.11.

${ }^{26}$ Cf. Bottoms, "5 Puzzles", pp.90-1 who is more concerned with the content or the source of the norm. It is not that these features are unimportant, but that he is not attending to the mode of responsibilization.

27 A point made by Bottoms, "5 Puzzles", pp.93-4
} 
illustrated by considering the phenomenon of mass imprisonment in the United States. ${ }^{28}$ Individual punishments may be legally valid, in the sense of imposed by legally constituted courts according to pre-established rules, and justified in terms of retribution or individual desert; the problem is that the system as a whole is criticised for illegitimacy because of overpunishment and the disproportionate impact on certain ethnic communities. This broader issue is not something that can be addressed only by limiting the amount of punishment (for example, calling for proportionally shorter sentences, or challenging the idea of desert) because punishment is part of a larger system where issues of social inequality and the political use of the criminal law are central. ${ }^{29}$ This is also linked to a further point, which is that it is implicit in this type of expressive account that punishment should articulate shared wrongs which encapsulate or reflect the views of the "community" or the wider society. The theory assumes the existence of moral consensus, or at least a potential for consensus, both in the identification of 'wrongs' and in the idea that criminal justice system actors are justified in acting on behalf of the community. ${ }^{30}$ The problem, though, is that the evidence in support of the existence of this kind of moral consensus about wrongdoing, or shared trust in the criminal justice system, is limited - and indeed that this kind of trust can be weakened by policies such as mass incarceration. ${ }^{31}$ The conceptual neatness of the theory arguably breaks down when it comes into contact with the actual practices of criminal justice systems or, indeed, actual social practices. ${ }^{32}$

\section{Rethinking Censure}

On the face of it there is little in common between these two accounts of censure. Von Hirsch's account is the epitome of an approach rejected by Sumner: an individualist account articulated in terms of a claim to universal values, which pays little heed to social context or power relations. Indeed, far from being an expression of power, the concept of censure, on von Hirsch's account, is viewed as a means of controlling or limiting power. Likewise, from von Hirsch's perspective, Sumner's account of censure might appear to lack normative grounding, and give insufficient weight to the significance of law as a particular kind of censuring practice. Both are universalising, but in hugely different ways. Von Hirsch's account seeks to identify the normative core of censuring practices in an account of moral agency; Sumner originally sees the concept of censure as a morally neutral term that will allow us to analyse a range of different censuring practices. While von Hirsch goes back to 'classical' theories of criminal law and moral philosophy to focus on questions of normative justification, Sumner is developing a meta-theoretical account of the political economy of law and crime. How, then, are we to think about the relation between the two ideas of censure? Are the two simply incommensurable, in spite of the common terminology? ${ }^{33}$ At one level I think this is certainly the case for the reasons set out above. However, in this final part of the

\footnotetext{
${ }^{28}$ M Alexander, The New Jim Crow. Mass Incarceration in the Age of Colorblindness (New York: The New Press, 2010); D Garland (ed), Mass Imprisonment. Social Causes and Consequences (London: Sage, 2001)

${ }^{29}$ V Chiao, "Mass Incarceration and the Theory of Punishment" forthcoming Criminal Law and Philosophy (DOI 10.1007/s11572-015-9378-x).

${ }^{30}$ See e.g. Censure and Sanctions, p.5 expressing a kind of Rawlsian view about a system of sanctions that all members of the community might in principle agree to.

${ }^{31}$ See e.g. C Muller \& D Schrage, "Mass Imprisonment and Trust in the Law" (2014) 651 Annals of the American Academy of Political Science 139-58.

${ }^{32}$ See L Farmer, Making the Modern Criminal Law. Criminalization and Civil Order (Oxford: Oxford UP, 2016), pp.103-15.

${ }^{33}$ Cf. P Roberts, "From Deviance to Censure. A 'New' Criminology for the Nineties" (1996) 59 Mod LR 125 44.
} 
paper I want to explore some possible ways of developing a common ground between the two accounts.

One possible starting place for doing this is Stan Cohen's paper "On Guilt, Justice and Tolerance" which, like both Sumner and von Hirsch, was responding to the collapse of the rehabilitative ideal and the breakdown of the post-war consensus in the 1970s. In this paper Cohen argued that an impasse had been reached: the 'new' or radical criminology was increasingly focused on the labelling processes, rather than a supposed underlying reality of 'crime' but, in doing so, failed to respond to concerns that people were the victims of crime or to recognise that (at least some) offenders deserved to be punished. By contrast Cohen acknowledged that part of the political appeal of the 'back to justice' movement, represented by people like von Hirsch, was that their critique of criminal justice rested on an appeal to normative concepts such as guilt and justice. Cohen accordingly challenged critical criminologists to address and articulate the normative presuppositions of their own work in order to re-engage with the political relevance of their work. ${ }^{34}$ The central claim that Cohen makes is that:

"the interests of the state lie in prohibiting certain action and punishing those responsible for this action. The questions these interests raise (and always have) about justice, tolerance, morality, guilt, and responsibility are only now being considered in the new criminologies. I believe it is only by putting them firmly on the agenda that the connections with criminal justice politics can be made." 35

For Cohen the immediate question was one of developing a new kind of criminal justice politics, such that radical criminology did not place itself in the position of the outright rejection of all forms of regulation or social control. In other words, he argued that criminologists should avoid a complete moral relativism, that saw all labels as arbitrarily imposed, and should instead interrogate the meanings of concepts such as guilt, responsibility and justice. These, he argued, were not necessarily only abstract conceptual building blocks cut off from any social reality, nor ideological cover for the naked exercise of power, but could also articulate socially meaningful practices in terms of which the conduct of social actors and institutions could be made judged. This involved the further recognition that an institution such as the criminal law (or something like it) was necessary to most (if not all) societies, as even socially just societies would require some sort of regulation of conduct and a system for allocating blame and making judgments. ${ }^{36}$ The point, therefore, for him was not to reject the criminal law (or an account of guilt and justice) outright, but to locate the discussion of legal practices and concepts in a broader critique by understanding how the institution had developed and whose interests it served, but also why the law continued to have a broad social appeal and to be a meaningful way of understanding and judging conduct. ${ }^{37}$ This project, it seems to me, is no closer to fulfilment than when Cohen wrote. However, by bringing together some of the insights from both accounts of censure, it is possible to outline how Cohen's basic insight might be developed.

Our starting point must be Cohen's claim that it is necessary to reflect on the question of the sense in which a person accused of having committed a crime might be guilty. This

\footnotetext{
${ }^{34}$ In S Cohen, Against Criminology (London: Transaction Books, 1988). Some similar issues were raised in G Pearson, The Deviant Imagination. Psychiatry, Social Work and Social Change (London: Macmillan, 1975) cautioning against the romanticization of deviance and recognizing that there will be a need for moral judgments. For a more recent discussion see S Cottee, "Judging Offenders: the moral implications of criminological theories" in M Cowburn et al, Values in Criminology and Community Justice (Bristol: Policy Press, 2013).

${ }^{35}$ Cohen, Against Criminology, p.117.

${ }^{36}$ Cohen, Against Criminology, p. 120.

${ }^{37}$ Ibid p.133 "locating justice model in broader critique and program".
} 
clearly is not a straightforward question to answer, as we should not simply fall back, as many moral philosophers do, on our supposed or assumed moral intuitions or emotions about the wrongfulness of conduct or the meaning of guilt. ${ }^{38}$ These are socially constructed and cannot be treated as though they give us any sort of direct access to truth. Guilt is a complex matter involving subjective feelings and judgments as well as being embedded in the long history of our legal, religious and moral institutions. ${ }^{39}$ One element of the reflection on guilt is the need to engage with the practices, the motives and the characters of those who break social norms - to decide, in Becker's terms, whose side we are on. ${ }^{40}$ This also relates to what Cottee has called the 'moral framing' of offenders within criminology, or the need for a reflexive criminology that is capable of articulating the moral implications of its explanatory models. ${ }^{41}$ A further dimension, though, is the need for criminologists (and criminal lawyers) to engage with the systems and institutions that identify and condemn offenders - something that more directly confronts Sumner's deployment of the concept of censure. Guilt is a moral concept, but it is also a legal concept, and while legal conceptions of guilt are related to moral conceptions, they also operate within, and are shaped by, a distinct set of institutions such as the criminal law. ${ }^{42}$ It is thus important to understand how the criminal law operates not only as a system of blame allocation but also as a system that gives meaning to certain forms of conduct. This is a matter of understanding the ways that it identifies forms of conduct to be censured, differentiates between different actions and actors, and the terms in which, and procedures through which, it condemns and punishes. And crucially, of course, it also means that we need to address the question of the sense in which certain forms of censure or punishment are deserved.

Neo-classical accounts of criminal law and punishment, such as that advocated by von Hirsch, have unquestionably taken the question of guilt seriously. Indeed, the commitment to deserved punishment in his theory was based, as we have seen, on the claim that the degree of deserved punishment could be calibrated to the degree of culpability - that censure was intrinsically related to guilt. This was articulated with the aim of reducing punishment though, as many commentators have pointed out, the adoption of the justice-model was accompanied in practice by a relentless increase in the lengths of sentences and the numbers of those imprisoned in many jurisdictions.$^{43}$ At the very least, this kind of retributive theory does not seem to have restrained punishment as it originally promised to do. A significant weakness of the theory, though, has been that this account of desert in punishment was not matched by a developed understanding of the concept of crime - that is to say that it largely took existing institutional structures for granted. It was, to this extent, a theory of punishment without an adequate theory of crime, and thus as a theory of censure it could have only limited impact because it had little to say about the justification for the criminalization of particular crimes or, more broadly, little understanding of practices of criminalisation in modern society. In order for the normative critique of punishment to bite, I would argue that it is necessary additionally to develop a social theory of censures, along the lines set out by Sumner, that engages with the forms of particular censures, the kinds of knowledge that they produce, and the interests that they serve. Crime and criminal law, in other words, are not

\footnotetext{
${ }^{38}$ See L Farmer, "Criminal Wrongs in Historical Perspective" in RA Duff et al, The Boundaries of the Criminal Law (Oxford: Oxford UP, 2010).

${ }^{39}$ See e.g. S Ashenden \& J Brown, “Guilt: Introduction” (2014) 43:1 Economy \& Society 1-18.

${ }^{40}$ H Becker, "Whose Side Are We On?" (1967) 14 Social Problems 239-47

${ }^{41}$ Cottee, "Judging Offenders" pp.17-18. See now S Armstrong et al, Reflexivity and Criminal Justice. Intersections of Policy, Practice and Research (London: Palgrave Macmillan, 2016).

${ }^{42}$ C Thornhill, "Guilt and the Origins of Modern Law" (2014) 43:1 Economy \& Society 103-35.

${ }^{43}$ See the discussion in N Lacey \& H Pickard, "The Chimera of Proportionality" (2015) $78 \operatorname{Mod}$ LR 216-40 at pp.224-8.
} 
neutral conduits between moral values and punishing practices but are intrinsically linked to the development of the modern state and to the particular project of social stabilisation and pacification that it drives. ${ }^{44}$

One of the central features of the development of the modern criminal law has been a culture of individualism, expressed in the central concept of criminal responsibility. ${ }^{45}$ Modern liberal criminal law individualises, and there is a justified fear that it is consequently overly reductive of complex social relationships, and that its focus on rational decision making reduces everything to a utility-maximising logic. ${ }^{46}$ The logic of individual responsibility in the criminal law has thus always sat awkwardly with sociologically oriented criminological explanations which have linked criminal conduct to structural and cultural explanations of the determinants of conduct. ${ }^{47}$ From this perspective criminal law is easily treated as a state institution that legitimises the exercise of class power, and it is then difficult, as Cohen pointed out, to negotiate a path between a kind of social determinism that denies agency and a recognition of free will that seems to concede the legitimacy of the criminal law. An alternative way of approaching responsibility in criminal law, however, is to distinguish, as von Hirsch's account of censure does, between a kind of methodological individualism, which sees individual agency (or free will) as a fixed feature of human nature, and the kind of account which sees responsibility as rooted in social practices of holding others to account. ${ }^{48}$ This kind of account sees responsibility as primarily relational, linked to different kinds of social processes and institutions through which members of particular communities are called on to answer for their conduct. The advantage of such an approach is that criminal responsibility is no longer seen as reflecting an underlying state of affairs (free will) which is antithetical to social theory, but is instead "rooted in the practices of defining the scope of responsibilities and of holding to account by the legal institution." 49 It is thus possible to distinguish between the practice of holding others responsible (censure in general), and the particular institutional forms that this takes. In other words, it is possible critically to assess particular practices of responsibilization in the modern criminal law, while still recognising that responsibility practices more generally are a fundamental feature of social life.

The question of criminal responsibility also requires us to address the question, raised by von Hirsch, of the specific characteristics of the criminal law as a censuring practice. A sociology of censures must acknowledge that there are different kinds of censuring practices and explore what it is that makes them distinctive. A key feature of criminal responsibility is that it creates a reasonably static object of legal attribution and application (the legal subject) which allows the articulation of norms capable of general application. ${ }^{50}$ That is to say that the institution of law posits that those to whom personality is attributed are those capable of acting in conformity to norms and being held responsible for breaches of those norms ${ }^{51}$ This is the basis for legal censuring practices, and while this might be criticised, as we noted above, as a kind of abstraction from social realities, presupposing the subject as a responsible agent in this way has further implications for the form or modality of law. Rules must take

\footnotetext{
${ }^{44}$ R Reiner, Crime (Cambridge: Polity, 2016) pp.2-3; Farmer, Making the Modern Criminal Law, ch.3.

${ }^{45} \mathrm{~N}$ Lacey, In Search of Criminal Responsibility. Ideas, Interests and Institutions (Oxford: Oxford UP, 2016).

${ }^{46}$ For the classic account see G Becker, "Crime and Punishment: An Economic Approach" (1968) 76 Jnl. Of

Political Economy 169-217.

${ }^{47}$ See e.g. the discussion in Cottee, "Judging Offenders" supra n.34.

${ }^{48}$ See the discussion in Kutz, supra n.22, at pp.552-8.

${ }^{49}$ See Farmer, Making the Modern Criminal Law, supra n.32, p.169. While writers like von Hirsch argue that this reflects a fundamental or underlying structure of moral agency (thus bringing it back to a kind of methodological individualism), I argue here that this is not a necessary feature of this account.

${ }^{50}$ Thornhill, "Guilt and the Origins of Modern Law" supra n.42.

${ }^{51} \mathrm{~N}$ MacCormick, Institutions of Law, (Oxford: Oxford UP, 2007) p.89.
} 
the form of general norms directed at and capable of being understood and followed by persons deemed to possess the necessary capacities; and the attribution of responsibility for the breach of a norm should extend only to those who are recognized as possessing such capacities. ${ }^{52}$ The criminal law, in short, attributes a unique kind of agency to its subjects, and in doing so is itself subject to certain constraints. Laws should take the form of rules of general application, punishment should only be imposed on those found guilty under legal procedures, and only to the extent of their guilt, and so on. This is not to suggest that criminal law always meets these aspirations, for this is unfortunately not the case, nor that the law is not used for instrumental ends or to serve the interests of particular social groups; but where it departs from these standards, applies them in a partial way, or directly prefers the interests of one class over another, it is open to challenge and undermines its own legitimacy. This might be viewed as a restatement of the point made so elegantly by EP Thompson in the context of his discussion of repressive eighteenth-century criminal laws:

"It is true that in history the law can be seen to mediate and to legitimize existent class relations. Its forms and procedures may crystallize those relations and mask ulterior injustice. But this mediation, through the forms of law, is something quite distinct from the exercise of unmediated force. The forms and rhetoric of law acquire a distinct identity which may, on occasion, inhibit power and afford some protection to the powerless." 53

This is important because both accounts of censure assume that it is justifiable to punish (presumably through law) genuinely harmful acts. There is, though, a crucial gap between the two accounts of censure, in that while von Hirsch's account assumes a community of interests which has reasonably settled understandings of wrongs and harms, Sumner advances a powerful critique of censuring practices in neo-liberal society and argues that there is a need for a new ethical code to censure the harmful practices of the wealthy and powerful. This, once again, brings in the question of the range of censuring practices, but it is not only a matter of the sociology of censure, but also of the social legitimacy of censuring practices or, more narrowly, the normative basis of criminalization. The normative basis of Sumner's critique is based, at least in part, on the relative degree of social harmfulness of certain types of conduct and on the continuing social exclusion of certain groups or communities - an exclusion that is reinforced by the practices of the criminal justice system. In pointing to the illegitimacy of neo-liberal censure, it appeals to the possibility of a different social basis for legitimacy. But this is where more work needs to be done, for if the limitations of von Hirsch's account of moral community are clear, we should be wary about replacing this with the claim to the existence of another, morally superior, community. The claim is perhaps better understood in a political register as a matter of opening up debate about the political legitimacy of the criminal law. A theory of censure should not be allowed to shut down such claims about political legitimacy, but should rather be used to open them up.

\section{Conclusion}

The concept of censure, as developed in different ways, in the work of Sumner and von Hirsch, has enormous potential - though each of the accounts has its own limitations - and this potential might be greater yet if we are able to draw on the strengths of both theories. In this chapter I have tried to show some way in which there is a common ground between them,

\footnotetext{
${ }^{52}$ Kutz, "Responsibility” supra n.22, p.567. cf. L Fuller, The Morality of Law (Revised edn.) (New Haven: Yale UP, 1969) pp.181-4; K Rundle, Forms Liberate (Oxford: Hart Publishing, 2012).

${ }^{53}$ EP Thompson, Whigs and Hunters. The Origins of the Black Act (Harmondsworth: Penguin, 1977) p.266.
} 
and to offer some suggestions as to ways that this common ground might be developed, bringing criminology and criminal law theory into a new kind of dialogue. 